\title{
PROFESZOROK AZ INNOVATÍV FIATALOKÉRT
}

\section{Szerző:}

Dr. Koncz István

Professzorok az Európai Magyarországért

Egyesület

Első szerző e-mail címe:

elnok@peme.hu
Lektorok:

Dr. Riesz Mária

Pünkösdi Teológia Főiskola

(Magyarország)

Dr. Tariszka Éva

Budapesti Gazdasági Egyetem

(Magyarország)

Koncz István (2018): Professzorok az innovatív fiatalokért. Különleges Bánásmód, IV. évf. 2018/1. szám, 89-91. DOI 10.18458/KB.2018.1.89

\section{Absztrakt:}

Jelen tanulmányban a Professzorok az Európai Magyarországért Egyesület (PEME) Professzorok az innovativ fiatalokért programját mutatjuk be, mely az NTP-PKTF-17-0016 pályázat keretében valósult meg.

Kulcsszavak: innováció, tehetség

Diszciplína: pedagógia

\begin{abstract}
PROFESSORS FOR YOUNG INNOVATORS

At this paper, we show on the 'Professors for Young Innovators' program of the Association of Professors for European Hungary, which realized in the frame of NTP-PKTF-17-0016 project.
\end{abstract}

Keywords: innovation, talent

Discipline: pedagogy

2003. márciusában 103 tudós, pedagógus, orvos, mérnök szándéka nyomán indult el, a mára a legtöbb felsőoktatási intézményben szakmai képviselettel bíró szervezet, a Professzorok az Európai Magyarországért Egyesület (PEME). A PEME abból a társadalmi igényből született, hogy több ezer reál- és humán értelmiségi szakmapolitikai területen szeretne bekapcsolódni a jövő tervezésébe és építésébe.

A PEME Alapszabálya és a kialakult gyakorlat szerint az európai és a magyar értékek kapcsolataira, közvetítésére és bemutatására koncentrál elsösorban, különféle munkaformákon keresztül. Az Egyesület alkot, kidolgoz, átvesz, közvetít, véleményez és minősít, közkinccsé tesz alapvető értékeket. 
Az Egyesület saját tevékenysége lényegében elválaszthatatlan tagjainak sokirányú értékteremtő tevékenységétől, ami részben a szervezeten belül történik, részben a szervezet befogadja, „importálja”, és közvetíti, terjeszti, népszerüsíti a tagok és csoportjaik által elért eredményeket. Itt is fontos kommunikációs feladatsor lép be, hogy a szervezetben jelen lévő és fejleszthető tudásbázis aktivizálása, hasznosítása, közkinccsé tétele megtörténhessen.

A mára megizmosodott alapvető munkaformák a következők: alapkérdések koncepcionálása, kutatások, életesélyekkel, jövőtervezéssel kapcsolatos konferenciák interneten folytatott viták, országos és területi konferenciák, szük körü és szélesebb szakmai bázist érintő szakmai viták, fiatal kutatók felkészítése a tudományos életre (12 PhDkonferencia és kötet), a sikeresebb személyes hatásra és az élet(újra)kezdésre, valamint a különös helyzetü fiatalokkal foglalkozók felkészítése a körükben folytatandó speciális tevékenységi formákra.

A szervezet tagjai - akadémikusok, professzorok, tanárok, mérnökök, orvosok, kutatók európai és nemzeti értékek mellett tették le a voksot, akik az értelmiség megteremtésében meghatározó szerepet játszanak. Külön érdekessége a szervezetnek, amelyben jelenleg 51 akadémikus is tevékenykedik, hogy sok fiatal tagja van.

\section{Programösszefoglaló}

A Professzorok az Európai Magyarországért Egyesület (PEME), “ Professzorok az innovatív fiatalokért" címmel,indított az Emberi Erőforrás Támogatáskezelö által támogatott egyéves programot 2017. július 1-től (pályázati azonosító: NTP-PKTF-17-0016).

A „Professzorok az innovatív fiatalokért”szakmai program 2018. június 30-ig tart, amelyet - küldetése szellemében - kettős céllal szervez a PEME, mint a legnagyobb országos értelmiségi támogató és érdekvédelmi szervezet. Elsődleges célja a 14-20 éves korosztály önmenedzselő, konfliktuskezelő-megoldó, innovációs és vezetői készségeinek fejlesztése, ugyanakkor célja a 16-35 éves korosztály számára önmenedzselést, önhatástudatot, sikeres én-prezentációt, innovatív gondolkodást, s a társadalmi felelősségvállalásra motiválást és szocializációt is biztosítani.

Mindkét programelem megvalósításába határon túli fiatalok (Újvidékről és Szlovákiából) bevonására is sor került. A résztvevők az ön-menedzselést (azon belül a stratégiai tervezést, időmenedzsment eszközeit, személyiségbeli sikertényezők, s kapcsolati tőke felmérést, benyomásmarketinget, siker- és kudarckezelést, konfliktusmegoldást stb.), az innovációs készségeket (azon belül a kreativitást és a prezentációs technikákat), illetve a vezetői készségeket (feladat meghatározás és kiosztás, csoportszervezés, motiválás, döntés, interperszonális konfliktusmegoldás, stb.) egyéni, páros, kiscsoportos feladatok révén gyakorolják.

A személyiségfejlesztés játékos önismereti gyakorlatokon keresztül valósult meg, mely gyakorlatok az innovatív tevékenységgel kapcsolatos önismereti, önértékelési, énkonfliktusmegoldási fókusszal rendelkeznek (pl. Alkalmas vagyok-e innovatív tevékenységre? Mik az erősségeim, melyek a gyenge oldalaim ezzel kapcsolatban? stb.).

Az innovációs környezet által támasztott kihívások során keletkező problémák esetében filmklub jellegü találkozót szervezésére került sor (felvezető előadással, filmnézéssel és megvitatással).

A programba bevont 212 fiatal neves külföldi gazdasági szakember interaktív előadása és tréneri tevékenysége segítségével ismerkedik meg a az innovációs környezet sajátságaival és résztvevőivel. Ennek eredményeképpen a bevont fiatalok lehetőségeket kapnak közvetlenül is konzultálni a téma nemzetközileg ismert szaktekintélyével.

A pályázatban a PEME szakmapolitikai mühelyeiben tevékenykedő vezető szakemberek közül 6 mentor vesz részt, akik közvetlen formában 2-2 (összesen 12) fö 16-35 év közötti bevont fiatallal tartják a kapcsolatot (érzékenyítik őket a témára, szakmai és személyi támaszt 
nyújtanak, szakmai kapcsolatrendszerükkel is támogatják, s felkészítik őket a prezentációs feladatok ellátására); közvetett formában pedig a bevont 14-20 éves korosztályt is segítik.

A 16-35 éves korcsoportba tartozó fiatalok által megvalósított projekt kiemelt tartalmi elemként kezeli a társadalmi felelősségvállalást. Alkalmazott tevékenységek, módszerek: előadás meghallgatása a társadalmi felelősségvállalásról, vázlat készítése egy fiktív cég vállalati társadalmi felelősségvállalási lehetőségeivel kapcsolatban. A programba bevont 1420 éves korosztály számára a 16-35 éves korosztályba tartozóknak kell érvelniük a társadalmi felelősségvállalás szükségességéről, fontosságáról és lehetőségeiről. A 14-20 éves korosztály számára pedig előadások, esetismertetések, s tréningek során a mentorok által irányítottan, általuk eljátszott esetjátékok révén szembesülnek a társadalmi felelősségvállalás jelentőségével. 